\title{
Mean age of carbon in fine roots from temperate forests and grasslands with different management
}

\author{
E. Solly ${ }^{1}$, I. Schöning ${ }^{1}$, S. Boch ${ }^{2}$, J. Müller ${ }^{3}$, S. A. Socher ${ }^{2}$, S. E. Trumbore ${ }^{1}$, and M. Schrumpf ${ }^{1}$ \\ ${ }^{1}$ Max Planck Institute for Biogeochemistry, Jena, Germany \\ ${ }^{2}$ Institute of Plant Sciences and Botanical Garden, University of Bern, Bern, Switzerland \\ ${ }^{3}$ Institute of Biochemistry and Biology, University of Potsdam, Potsdam, Germany \\ Correspondence to: E. Solly (esolly@bgc-jena.mpg.de)
}

Received: 25 January 2013 - Published in Biogeosciences Discuss.: 22 March 2013

Revised: 7 June 2013 - Accepted: 16 June 2013 - Published: 17 July 2013

\begin{abstract}
Fine roots are the most dynamic portion of a plant's root system and a major source of soil organic matter. By altering plant species diversity and composition, soil conditions and nutrient availability, and consequently belowground allocation and dynamics of root carbon $(\mathrm{C})$ inputs, land-use and management changes may influence organic $\mathrm{C}$ storage in terrestrial ecosystems. In three German regions, we measured fine root radiocarbon $\left({ }^{14} \mathrm{C}\right)$ content to estimate the mean time since $\mathrm{C}$ in root tissues was fixed from the atmosphere in 54 grassland and forest plots with different management and soil conditions. Although root biomass was on average greater in grasslands $5.1 \pm 0.8 \mathrm{~g}$ (mean $\pm \mathrm{SE}$, $n=27)$ than in forests $3.1 \pm 0.5 \mathrm{~g}(n=27)(p<0.05)$, the mean age of $\mathrm{C}$ in fine roots in forests averaged $11.3 \pm 1.8 \mathrm{yr}$ and was older and more variable compared to grasslands $1.7 \pm 0.4 \mathrm{yr}(p<0.001)$. We further found that management affects the mean age of fine root $\mathrm{C}$ in temperate grasslands mediated by changes in plant species diversity and composition. Fine root mean $\mathrm{C}$ age is positively correlated with plant diversity $(r=0.65)$ and with the number of perennial species $(r=0.77)$. Fine root mean $\mathrm{C}$ age in grasslands was also affected by study region with averages of $0.7 \pm 0.1 \mathrm{yr}$ $(n=9)$ on mostly organic soils in northern Germany and of $1.8 \pm 0.3 \mathrm{yr}(n=9)$ and $2.6 \pm 0.3(n=9)$ in central and southern Germany $(p<0.05)$. This was probably due to differences in soil nutrient contents and soil moisture conditions between study regions, which affected plant species diversity and the presence of perennial species. Our results indicate more long-lived roots or internal redistribution of $\mathrm{C}$ in perennial species and suggest linkages between fine root $\mathrm{C}$ age and management in grasslands. These findings improve our ability to predict and model belowground $\mathrm{C}$ fluxes across broader spatial scales.
\end{abstract}

\section{Introduction}

In terrestrial ecosystems, plant fine roots (defined here as $<2 \mathrm{~mm}$ in diameter) play an important role in biogeochemical cycling (Brunner and Godbold, 2007). The flux of $\mathrm{C}$ from plants to soil includes allocation to grow and maintain roots, and to support supply of $\mathrm{C}$ to the rhizosphere. Fine roots are considered to be the most dynamic part of the root system and to control the acquisition of water and nutrients from the soil (Lukac, 2012). However, estimating the amount of $\mathrm{C}$ allocated in fine roots and the turnover times of root systems are still challenges in ecology. Furthermore, our ability to observe directly and quantify roots in situ is limited (Majdi et al., 2005; Trumbore and Gaudinski, 2003)

Estimates of $\mathrm{C}$ allocation to root growth and maintenance have been based on the assumption that fine roots turn over approximately annually (Jackson et al., 1997). However, measurements of isotopes in fine roots demonstrated that both the ${ }^{14} \mathrm{C}$ age (Gaudinski et al., 2001) and the incorporation rate of a continuous ${ }^{13} \mathrm{C}$ label (Matamala et al., 2003) in fine root $\mathrm{C}$ were inconsistent with an annual turnover. The various observations can be reconciled by assuming that fine roots are not a single homogeneous pool (Gaudinski et al., 2010; Guo et al., 2008; Strand et al., 2008; Tierney and Fahey, 2002; Trumbore, 2009). To date, published fine root radiocarbon $\left({ }^{14} \mathrm{C}\right)$ data are mostly from forest ecosystems and little is known of how these observations apply to non-forested ecosystems, or a range of forest types (Fröberg, 2012; Gaudinski et al., 2010; Riley et al., 2009). Identifying predictors of fine root $\mathrm{C}$ age is of specific importance to develop indices of root dynamics and modelling efforts given the pressing need to improve our knowledge about belowground C fluxes (Ostle et al., 2009). 
Management intensification and land-use changes are considered to be the main processes eroding species diversity (Laliberté et al., 2010). Changes in plant species can influence ecosystem nutrient dynamics by a variety of mechanisms including biomass production, decomposition and nutrient cycling (Hättenschwiler et al., 2005; Hobbie, 1992; Tilman et al., 1996). However, the mechanisms by which management-driven alterations of plant species diversity, and soil conditions including moisture, $\mathrm{pH}$ and nutrient availability can affect mean ages of fine root $\mathrm{C}$ and belowground $\mathrm{C}$ cycling remain unclear (Schmidt et al., 2011). For example, older roots may occur in less fertile sites because plants invest less in new tissues than plants in nutrient-rich sites (Chapin et al., 2002). Thus, differences in the mean age of root $\mathrm{C}$ between trees and grasses, or perennial and annual plants, could reflect differences in plant resource conservation and acquisition strategies between species or functional types. These in turn can reflect differences in root anatomy, chemistry and architecture, and the capacity for internal recycling of $\mathrm{C}$ in perennial root systems. Predicting ecosystem responses to environmental change requires understanding of root dynamics from a range of vegetation covers representing forests and grasslands across a large spatial scale and over a range of managements and soil types. To address some of these questions, plant species may be classified according to their ecological behaviour (i.e. Ellenberg's ecological indicator values; Ellenberg et al., 2001), to summarize environmental factors like soil moisture and available nitrogen (N) content. However, those factors such as moisture and the available $\mathrm{N}$ content in the soil can be altered by management and climate during the growing season.

Radiocarbon measurements of roots are a useful measure for understanding belowground carbon fluxes, if the root carbon pools of interests are defined appropriately (Majdi et al., 2005). ${ }^{14} \mathrm{C}$ is a radioactive isotope (half-life $5730 \mathrm{yr}$ ) which is naturally present in the atmosphere. Thermonuclear weapon explosions in the atmosphere also produce radiocarbon and during the 1950s and early 1960s nearly doubled the amount in the Northern Hemisphere atmosphere. Since the nuclear test ban treaty in 1963 , atmospheric ${ }^{14} \mathrm{C}$ values have been declining through atmospheric mixing, incorporation into terrestrial and aquatic $\mathrm{C}$ pools and dilution by combustion of ${ }^{14} \mathrm{C}$ free fossil fuels. The documented time history of atmospheric "bomb" ${ }^{14} \mathrm{C}$ provides a global isotope tracer of the carbon cycle (Naegler and Levin, 2006; Randerson et al., 2002). Plants fixing atmospheric $\mathrm{CO}_{2}$ record its ${ }^{14} \mathrm{C}$ signature, once data are corrected for mass-dependent isotopic fractionation (Stuiver and Polach, 1977). The precision of ${ }^{14} \mathrm{C}$ measurements using accelerator mass spectroscopy (AMS; $\pm 2-3 \%$ ) combined with the recent rate of ${ }^{14} \mathrm{C}$ decline of $\sim 4-5 \%$ o per year (Levin et al., 2010) enables us to use radiocarbon as a tool for determining the average time elapsed between $\mathrm{C}$ fixation and its incorporation into root tissues (Gaudinski et al., 2001). Accordingly, ${ }^{14} \mathrm{C}$ investiga- tions can be used to estimate average fine root $\mathrm{C}$ ages rather than the direct turnover time of root systems.

Here we use ${ }^{14} \mathrm{C}$ to estimate root $\mathrm{C}$ age of fine roots samples in 27 grasslands and 27 forest plots with different management in three regions in Germany, with a steady-state model implemented by Gaudinski et al. (2001). Because part of the overall $\mathrm{C}$ age might reflect plant allocation of older carbon to the root system, we use the term "fine root C age" instead of fine root age. Our main objective is to evaluate the differences in the mean age of the standing stock of $\mathrm{C}$ in root biomass in grassland and forest sites under diverse management, plant species diversity and soil properties. We are also interested in understanding if the mean age of $\mathrm{C}$ in fine roots is related to fine root nutrient concentration and root biomass. We hypothesize that (i) in forest ecosystems the age of root carbon is older than in grasslands due to the greater ability of trees to use storage compounds and recycle $\mathrm{C}$ internally; (ii) in grasslands the management effect is reflected in the mean age of fine root $\mathrm{C}$ and is mediated by the total number of perennial species present; (iii) ${ }^{14} \mathrm{C}$ of fine roots differs between study regions mainly driven by differences in soil characteristics (e.g. nutrient contents) and climate.

\section{Materials and methods}

\subsection{Study regions}

The research was carried out in 54 plots distributed in three German regions, the so-called Biodiversity Exploratories (Fischer et al., 2010), which comprise a variety of forests and grasslands managed with different intensities. The Schwäbische Alb (ALB) is situated in south-western Germany, the Hainich-Dün (HAI) in central Germany and the Schorfheide-Chorin (SCH) in north-eastern Germany. The three study regions differ in climate, altitude and soil characteristics (Table 1; for details, see Fischer et al., 2010).

In each region we selected 9 grassland and 9 forest plots to span a range of land-use intensities. In grasslands of the ALB and SCH, we selected three plots of different land uses: unfertilized pastures, fertilized meadows and mown pastures. The mown pastures were unfertilized in $\mathrm{SCH}$ and fertilized in ALB. In forests of the ALB and SCH, we selected three European beech (Fagus sylvatica $\mathrm{L}$.) dominated unmanaged stands, three European beech dominated ageclass managed forests and three conifer plantations (Norway spruce (Picea abies (L.) H. Karst) in the ALB and Scots pine (Pinus sylvestris $\mathrm{L}$.) in the $\mathrm{SCH}$ ). For the HAI we followed a different plot-selection scheme, and selected 9 grassland and 9 forest plots following gradients of soil texture and land-use intensity. Land-use intensity in HAI grasslands was quantified as a land-use intensity index (LUI) summarizing the individual land uses by summing up values for fertilization ( $\mathrm{kg} \mathrm{N}$ per hectare per year), mowing (times mown per year), and grazing intensities (livestock units per hectare per year), 
Table 1. Main geographical and environmental characteristics of the three study regions.

\begin{tabular}{llll}
\hline & ALB & HAI & SCH \\
\hline Location & SW Germany & Central Germany & NE Germany \\
Coordinates & $48^{\circ} 26^{\prime} \mathrm{N}, 9^{\circ} 23^{\prime} \mathrm{E}$ & $51^{\circ} 9^{\prime} \mathrm{N}, 10^{\circ} 28^{\prime} \mathrm{E}$ & $53^{\circ} 0^{\prime} \mathrm{N}, 13^{\circ} 46^{\prime} \mathrm{E}$ \\
Area & $\sim 422 \mathrm{~km}^{2}$ & $\sim 1300 \mathrm{~km}^{2}$ & $\sim 1300 \mathrm{~km}^{2}$ \\
Soil type forest & Cambisol (Eutric) & Luvisols & Cambisol (Dystric) \\
Soil type grasslands & Leptosol/Cambisol & Cambisol/Stagnosol & Histosol/Gleysol \\
Altitude a.s.l. & $460-860 \mathrm{~m}$ & $285-550 \mathrm{~m}$ & $3-140 \mathrm{~m}$ \\
Annual mean temperature & $6.0-7.0^{\circ} \mathrm{C}$ & $6.5-8.0^{\circ} \mathrm{C}$ & $8.0-8.5^{\circ} \mathrm{C}$ \\
Annual mean precipitation & $700-1000 \mathrm{~mm}$ & $500-800 \mathrm{~mm}$ & $500-600 \mathrm{~mm}$ \\
\hline
\end{tabular}

which have been normalized by the mean of the appropriate land-use type in order to standardize the scales (Blüthgen et al., 2012).

To evaluate land-use and disturbance intensity in the forests, we used an index called LUDI. This index was established by Luyssaert et al. (2011) by combining values of stand density and diameter at breast height for a relatively unmanaged forest and different management schemes, in conjunction with self-thinning values. The LUDI is calculated as the sum of two components: the "planning intensity", which relates to the potential stand density and the associated changes in diameter, and the "operational intensity", which relates to the standing biomass (or diameter) at a given stand density. Thus, the LUDI distinguishes between the long and short timescales which are associated with management and disturbance.

\subsection{Soil and root sampling}

Root sampling took place in early May 2011. On each plot we collected 14 mineral soil cores using a split tube sampler with a diameter of $5 \mathrm{~cm}$. In the forest sites organic layers were collected and removed before coring; in grasslands, aboveground portions of plants were removed. Cores were taken along two transects which were always selected in the same relationship to the overall plot. The two transects were $20 \mathrm{~m}$ long in grasslands and $40 \mathrm{~m}$ long in forests; the soil cores were evenly collected at a distance of $7 \mathrm{~m}$ in the forests and of $3 \mathrm{~m}$ in the grasslands. We then opened the core and cut a section representing a fixed sampling depth of 0 to $10 \mathrm{~cm}$ for further analysis. We prepared composite samples by mixing the material collected from the 14 cores. Roots were then removed from the composite sample, refrigerated at $4{ }^{\circ} \mathrm{C}$ and transported to the laboratory. Then, we removed the soil particles attached to the roots by cleaning them with distilled water in a $500 \mathrm{~mm}$ sieve and collected the fine roots with a diameter $<2 \mathrm{~mm}$. Dead roots were removed from the $<2 \mathrm{~mm}$ samples based on qualitative visual characteristics, including colour and breakability. Fine root samples were dried at $40^{\circ} \mathrm{C}$ to constant weight in a force-air oven. The roots were stored in plastic bags at room temperature until analysis.

\subsection{Biomass, $\mathrm{C}$ and $\mathrm{N}$ concentrations and $\mathrm{C}$ and $\mathrm{N}$ stocks of fine roots}

We weighed the dry biomass of the fine roots after drying. Total $\mathrm{C}$ and $\mathrm{N}$ concentrations of ground fine root material were analysed using an elemental analyser "Vario EL" (Elementar Analysensysteme GmbH, Hanau, Germany). Spruce needles (CRM 101 with $51.44 \% \mathrm{C} ; 1.889 \% \mathrm{~N}$ ) were used as reference material. Root samples collected in the grasslands, which in our plots are characterized by higher $\mathrm{pH}$ values $(5$ to 7.5 ) than forests (3.0 to 6.0), were decalcified in order to avoid carbonate contamination. Carbon and nitrogen stocks of fine roots $(0-10 \mathrm{~cm}$ depth) were calculated from the total carbon and nitrogen concentrations in the roots and from the dry biomass values of each sample.

\subsection{Management data, vegetation survey and soil characteristics}

In forests, land use was verified with a systematic inventory of a circular sampling area of $500 \mathrm{~m}^{2}$ (Fischer et al., 2010). In grasslands, land-use intensity data were obtained from a questionnaire for all land users. Forests were not fertilized. In 2008, we recorded the vegetation in forests in spring and again in summer, and in grasslands only once in summer. Plots in grasslands were $4 \mathrm{~m} \times 4 \mathrm{~m}$ and in forests $20 \mathrm{~m} \times 20 \mathrm{~m}$. We identified all vascular plant species and estimated their percentage cover. To assess the diversity of the vascular plant species in the forest plots, we combined the spring and summer records in order to consider early and late emerging plants. We calculated the "Shannon index" as a measure of plant species diversity. This index is based on an expression elaborated by Shannon for his mathematical theory of communication, where $H$ corresponds to the entropy (Shannon, 1948) (Eq. 1):

$H^{\prime}=-\sum_{i=1}^{n} p_{i} \ln p_{i}$.

$p_{i}$ is the percentage of the individuals represented by species $i$ and is assessed by the quotient of number of individuals of species $i\left(N_{i}\right)$ and the total number of individuals $(N)$. Thus, the maximum diversity possible for $N$ individuals occurs when each individual belongs to a different species. 
We further calculated the total number of annual and perennial species per plot. We used Ellenberg indicator values for "moisture" and "nitrogen" for each plot. These indicator values represent a measure of the realized ecological niche on an ordinal scale from 1 to 9 (Ellenberg et al., 2001) and are considered to be a valuable tool that can perform well (Schaffers and Sýkora, 2000).

We also measured soil $\mathrm{pH}$ of the same combined mineral soil samples from which we collected the roots. Soil samples were air-dried and sieved to $<2 \mathrm{~mm}$. Then, we calculated the mean of two $\mathrm{pH}$ measurements per soil sample, which were analysed in a $0.01 \mathrm{M} \mathrm{CaCl}_{2}$ solution with a soil solution ratio of $1: 2.5$.

\subsection{Radiocarbon measurements and root $\mathrm{C}$ mean age}

We measured the ${ }^{14} \mathrm{C}$ content of the ground fine root samples at the accelerator mass spectrometry (AMS) facility in Jena, Germany (Steinof et al., 2004). After combusting the samples, the resulting $\mathrm{CO}_{2}$ was catalytically reduced to graphite at $625{ }^{\circ} \mathrm{C}$ by $\mathrm{H}_{2}$ reduction. An aliquot of the $\mathrm{CO}_{2}$ was used to determine the $\delta^{13} \mathrm{C}$ of the sample. We express radiocarbon data as $\Delta^{14} \mathrm{C}$, which is defined as the difference in parts per thousand (\%o) between the ${ }^{14} \mathrm{C} /{ }^{12} \mathrm{C}$ ratio in the sample, corrected for mass-dependent isotope fractionation to a common $\delta^{13} \mathrm{C}$ value of $-25 \%$, in comparison to an oxalic acid universal standard (Trumbore, 2009) (Eq. 2). The standard is corrected for decay between 1950 and the year of the measurement $y$, which for the present work was 2011.

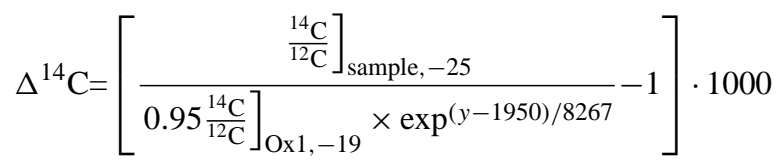

We further derived the mean $\mathrm{C}$ age of fine roots, which represents the time $\mathrm{C}$ was stored in the plant before being allocated for root growth, plus the root average lifespan. For our composite root samples, we chose a steady-state model implemented by Gaudinski et al. (2001). This method includes the ${ }^{14} \mathrm{C}$ concentration of atmospheric $\mathrm{CO}_{2}$ over the past $n$ years, where $n$ represents the average age of the root composite sample assuming that any variation in ages of the root mixture is normally distributed around the mean (Gaudinski et al., 2001). The equation we used is Eq. (3):

$C_{(t)} \times R_{\text {root }(t)}=I \times R_{\mathrm{atm}(t)}+C_{(t-1)} \times R_{\mathrm{root}(t-1)} \times(1-k-\lambda)$

In this method $C$ is the carbon stock of fine roots expressed in $\mathrm{g} \mathrm{C} \mathrm{m}^{-2}, I$ the input of $C$ by new production of fine roots in $\mathrm{g} \mathrm{C} \mathrm{m}^{-2} \mathrm{yr}^{-1}, k$ the multiplicative inverse of the mean age of fine root $\mathrm{C}$ age in $\mathrm{yr}^{-1}$, and $t$ equals the time (yr) for which the calculation is being performed. $R_{\text {root }}$ is calculated as $\left[\Delta{ }^{14} C_{\text {root }} / 1000+1\right]$ (Torn et al., 2009); $\lambda$ is the radioactive decay constant for ${ }^{14} \mathrm{C}(1 / 8267 \mathrm{yr})$. For the time history of radiocarbon $\left(R_{\mathrm{atm}}\right)$ at the three sites, we used Levin et al. (2010), updated to 2012 (personal communication). An

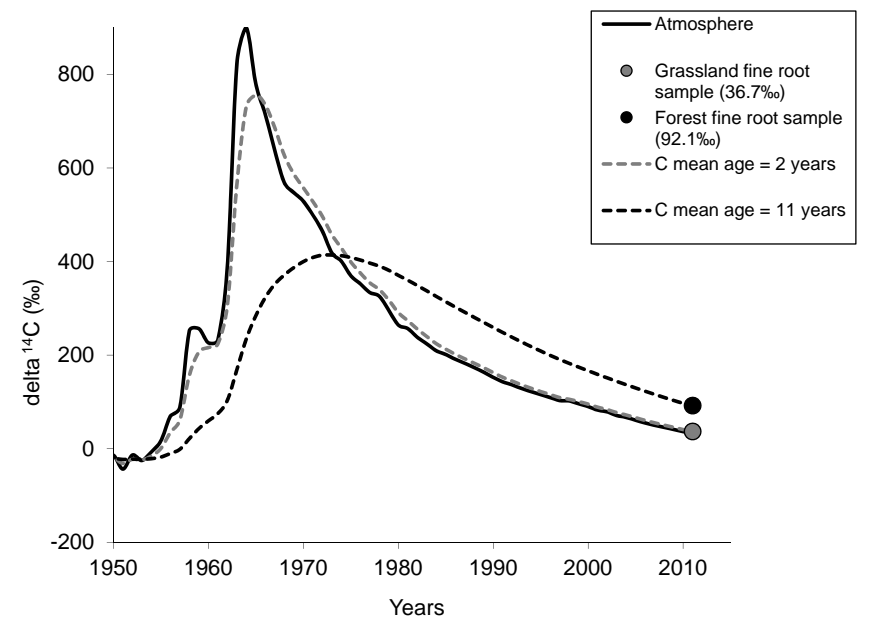

Fig. 1. Example of the model we used to determine the mean age of fine root $\mathrm{C}$ from the ${ }^{14} \mathrm{C}$ signature of the fine roots (Gaudinski et al., 2001).

example of the method for using ${ }^{14} \mathrm{C}$ values to estimate the mean age of $\mathrm{C}$ in fine roots is illustrated in Fig. 1. The atmospheric ${ }^{14} \mathrm{CO}_{2}\left(R_{\mathrm{atm}}\right)$ value for spring 2011 is equal to $(1.034$, or $34 \% / 1000+1)$. The model assumes a constant input and output of $\mathrm{C}$ to the root fraction every year. Thus, significantly large variations of storage capacities and fluxes between years (for instance, a greater root production in dry years rather than wet years, or a larger consumption of old storage compounds in dry years) might bias the results of the model. Further, the model assumes a homogeneous pool of roots. Therefore, it is possible that by using this method we are averaging more than one pool, i.e. short-lived roots and long-lived roots (Gaudinski et al., 2010). Local release of fossil $\mathrm{C}$ can impact the mean ${ }^{14} \mathrm{C}$ signature at any or all of our sites, which would tend to reduce the $\mathrm{R}_{\mathrm{atm}}$, and can potentially lead to $\Delta{ }^{14} C_{\text {root }}$ values lower than $34 \%$ (i.e. contemporary roots were formed in 2011 from freshly fixed photosynthetic products). The presence of fossil C signatures would serve to underestimate systematically the age of root $\mathrm{C}$; since we did not encounter many samples with $\Delta{ }^{14} \mathrm{C}$ below the current atmosphere, and mostly in the SCH grasslands, we do not think there is a large systematic bias in our results.

\subsection{Statistics}

We conducted all analyses with the R version 2.15.2 (R Development Core Team 2012). To examine statistical differences of biomass, $\mathrm{C}$ and $\mathrm{N}$ concentrations and stocks, ${ }^{14} \mathrm{C}$ content and mean $\mathrm{C}$ age of fine roots across the three study regions and between grasslands and forests, we used twoway analysis of variance (ANOVA) accompanied by Holm's test. To detect statistical differences of plant diversity and perennial species present on plot among study regions in the grasslands, we used one-way ANOVA. We present data as 
means \pm standard error. We used linear least-squares to compare correlations among all variables. For the grassland sites, we determined the Cox proportional hazards test (Cox, 1972) to identify the risk ratio of different variables on fine root $\mathrm{C}$ mean age. We used linear regression to assess the effect of plant diversity, number of perennial species, root nutrient concentrations, Ellenberg indicator values for soil moisture and available $\mathrm{N}$ content on the mean age of fine roots. Prior to analysis we transformed data if necessary to meet assumptions of normality. For all statistical tests, we use a significance level of 0.05 .

\section{Results}

\subsection{Fine root biomass and $\mathrm{C}$ and $\mathrm{N}$ stocks}

Fine root biomass was greater in grasslands than in the forests of the $\mathrm{SCH}(p<0.001)$, although this pattern was not observed to be significant in the HAI and ALB study regions (Table 2). In grasslands, fine root biomass was greater in SCH and HAI than in the ALB, while in the forests HAI had the highest biomass, followed by ALB and SCH (Table 2). Carbon concentrations of roots were higher in the forest sites compared to the grassland sites for all study regions $(p<0.05)$. Further, total C concentrations were observed to be significantly higher in SCH and ALB than in HAI for both grasslands and forests. Total fine root $\mathrm{N}$ concentrations did not differ significantly among forests and grasslands (Table 3), although in grasslands higher $\mathrm{N}$ concentrations were observed in the $\mathrm{SCH}$, followed by HAI and ALB (Table 2). C and $\mathrm{N}$ stocks of roots reflected patterns of biomass (Table 2).

\subsection{Fine root radiocarbon in grasslands and forests}

Most ${ }^{14} \mathrm{C}$ values exceeded the contemporary atmospheric mean (34\%o in spring 2011), indicating that the fine root samples analysed in this study contained a detectable proportion of "bomb" carbon fixed from the atmosphere after 1964. In the forests, fine root mean ${ }^{14} \mathrm{C}$ values exceeded the contemporary atmospheric average in all study regions by 53 to $58 \%$. In the grasslands, mean fine root ${ }^{14} \mathrm{C}$ values also exceeded the contemporary atmospheric mean by $6 \%$ in ALB and $2 \%$ in $\mathrm{HAI}$, while in $\mathrm{SCH}$ the average root ${ }^{14} \mathrm{C}$ values were lower than atmospheric ${ }^{14} \mathrm{C}$ values for 2011 by $2 \%$.

Overall, the greatest difference in fine root $\Delta{ }^{14} \mathrm{C}$ values was between forests and grasslands (Table 4), with significantly higher and more variable $\Delta^{14} \mathrm{C}$ in the forest sites, ranging from $135 \%$ o to $50 \%$, than in grasslands with fine root ${ }^{14} \mathrm{C}$ values ranging from $49 \%$ to $26 \%$. Due to the major variation of fine root ${ }^{14} \mathrm{C}$ values, we did not encounter any significant effects of changes in plant diversity, management and root quality on the fine root carbon age in forests.

The ${ }^{14} \mathrm{C}$ values of fine roots collected in the forest sites did not differ significantly between study regions, although the variability in ALB was higher $88 \pm 12 \%$ o than in HAI
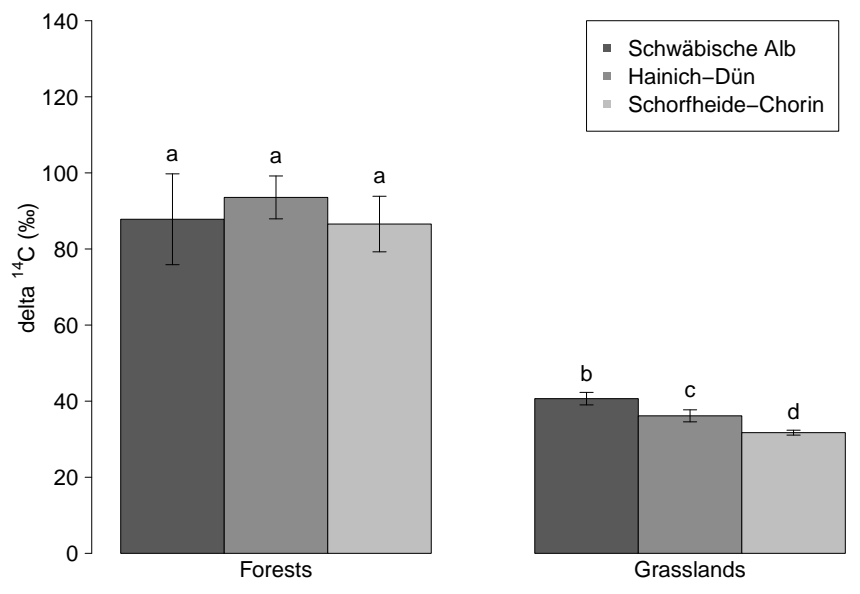

Fig. 2. Comparison of mean $\Delta^{14} \mathrm{C}$ values of fine roots between grassland and forest sites across study regions $(p<0.001)$. The columns denoted with different letters are significantly different $(p<0.05)$. Error bars represent SE of means $(n=9)$.

$94 \pm 6 \%$ and $\mathrm{SCH} 87 \pm 7 \%$ o. This corresponds to mean ages of 5 to $30 \mathrm{yr}$ in the ALB, 8 to $16 \mathrm{yr}$ in the HAI and 6 to $16 \mathrm{yr}$ in the SCH. In contrast, root ${ }^{14} \mathrm{C}$ values were less variable in grasslands, and significant variations among the three study regions were detected (Table 4, Fig. 2). The ${ }^{14} \mathrm{C}$ content of bulk live fine roots in the ALB grasslands had a mean value of $40 \pm 2 \%$ indicating mean ages overall ranging from 1 to $5 \mathrm{yr}$, whereas the root samples from the HAI grasslands showed mean ${ }^{14} \mathrm{C}$ values of $36 \pm 2 \%$ with ages ranging from 0 to $3 \mathrm{yr}$, and the $\mathrm{SCH}$ grasslands had the lowest ${ }^{14} \mathrm{C}$ values $32 \pm 1 \%$ with ages of 0 to $1 \mathrm{yr}$.

\subsection{Effect of plant diversity and number of perennial species on fine root $\mathbf{C}$ mean age in grasslands}

In grasslands, plant species diversity (Shannon diversity) was positively correlated with the total number of perennial species (Table 5). Further, across all study regions the mean age of fine roots in grasslands increases with species diversity and with the number of perennial species $(p<0.001$, Fig. 3). The unit risk ratios indicated that higher plant diversity and greater presence of perennial species significantly increased the mean age of $C$ in roots (Table 6). Mean plant diversity was largest in ALB $(2.3 \pm 0.1)$, followed by HAI $2 \pm 0.1$ and $\mathrm{SCH} 1.6 \pm 0.1(p<0.05)$ according to one-way ANOVA analysis. Also the average number of perennial species was observed to be higher in ALB $29 \pm 4$ followed by HAI $22 \pm 3$ and SCH $15 \pm 1(p<0.05)$ according to oneway ANOVA analysis. Plant diversity ranged from 1.0 to 2.9 (mean: $2.0 \pm 0.1$ ) and declined significantly for increasing values of soil available $\mathrm{N}$ and soil moisture according to the Ellenberg indicator values $(p<0.05$, Table 5$)$. The absolute number of perennial species present on plots ranged from 11 on plots characterized by higher soil available $\mathrm{N}$ content to 47 on plots characterized by lower soil available $\mathrm{N}$ 
Table 2. Root biomass, $\mathrm{C}$ and $\mathrm{N}$ concentrations and $\mathrm{C}$ and $\mathrm{N}$ stocks in fine roots $(<2 \mathrm{~mm})$ among different land uses and study regions (mean $\pm \mathrm{SE}$ ). Significant differences between study regions are indicated by lowercase letters and between land-use types by capital letters, according to Holm's test $(p<0.05)$.

\begin{tabular}{|c|c|c|c|c|c|c|c|}
\hline Land use & $\begin{array}{l}\text { Study } \\
\text { region }\end{array}$ & $n$ & $\begin{array}{c}\text { Root biomass } \\
\text { (g) }\end{array}$ & $\begin{array}{c}\text { C conc. } \\
(\%)\end{array}$ & $\begin{array}{c}\text { N conc. } \\
(\%)\end{array}$ & $\begin{array}{c}\text { C stocks } \\
\left(\mathrm{gC} \mathrm{m}^{-2}\right)\end{array}$ & $\begin{array}{l}\text { N stocks } \\
\left(\mathrm{g} \mathrm{C} \mathrm{m}^{-2}\right)\end{array}$ \\
\hline \multirow[t]{4}{*}{ Forest } & All plots & 27 & $3.1 \pm 0.5^{\mathrm{A}}$ & $47.2 \pm 0.8^{\mathrm{A}}$ & $\mathbf{1 . 1} \pm \mathbf{0 . 0 3}^{\mathrm{A}}$ & $51.1 \pm 7.7^{\mathrm{A}}$ & $1.2 \pm 0.2^{\mathrm{A}}$ \\
\hline & ALB & 9 & $2.8 \pm 0.7^{\mathrm{a}}$ & $48.8 \pm 0.7^{\mathrm{a}}$ & $1.2 \pm 0.1^{\mathrm{a}}$ & $39.7 \pm 9.7^{\mathrm{a}}$ & $0.9 \pm 0.2^{\mathrm{a}}$ \\
\hline & HAI & 9 & $4.9 \pm 1^{\mathrm{b}}$ & $42.8 \pm 1.1^{\mathrm{b}}$ & $1.1 \pm 0.04^{\mathrm{a}}$ & $79.9 \pm 16.4^{\mathrm{b}}$ & $2.0 \pm 0.4^{\mathrm{b}}$ \\
\hline & $\mathrm{SCH}$ & 9 & $1.7 \pm 0.4^{\mathrm{a}}$ & $49.9 \pm 0.8^{\mathrm{a}}$ & $1.1 \pm 0.1^{\mathrm{a}}$ & $33.8 \pm 7.6^{\mathrm{a}}$ & $0.7 \pm 7.6^{\mathrm{a}}$ \\
\hline \multirow[t]{4}{*}{ Grasslands } & All plots & 27 & $5.1 \pm 0.8^{B}$ & $41.8 \pm 0.5^{B}$ & $1.2 \pm 0.1^{\mathrm{A}}$ & $80.24 \pm 13.4^{B}$ & $2.4 \pm 0.5^{B}$ \\
\hline & ALB & 9 & $1.7 \pm 0.6^{\mathrm{a}}$ & $41.7 \pm 0.7^{b}$ & $0.9 \pm 0.5^{\mathrm{a}, \mathrm{b}}$ & $20.4 \pm 3.4^{\mathrm{a}}$ & $0.4 \pm 0.1^{\mathrm{a}}$ \\
\hline & HAI & 9 & $6.2 \pm 0.7^{b}$ & $39.9 \pm 1.1^{\mathrm{c}}$ & $1.1 \pm 0.1^{\mathrm{a}, \mathrm{c}}$ & $92.04 \pm 11.9^{b}$ & $2.4 \pm 0.8^{\mathrm{b}}$ \\
\hline & $\mathrm{SCH}$ & 9 & $7.4 \pm 1.7^{b}$ & $43.8 \pm 0.4^{b}$ & $1.6 \pm 0.1^{\mathrm{d}}$ & $128.2 \pm 29.2^{b}$ & $4.5 \pm 2.92^{b}$ \\
\hline
\end{tabular}

Table 3. ANOVA results of fine root biomass, $\mathrm{C}$ and $\mathrm{N}$ concentrations and stocks, to compare variance between study regions and differences between grasslands and forests (defined here as land use).

\begin{tabular}{lccc|ccc|ccc}
\hline & \multicolumn{3}{c}{ Study region } & \multicolumn{3}{c}{ Land use } & \multicolumn{3}{c}{ Study region $\times$ Land use } \\
\cline { 2 - 10 } Dependent variable & df & $F$ & $P$ & df & $F$ & $P$ & df & $F$ & $P$ \\
\hline Root biomass & 2 & 9.67 & $<0.001$ & 1 & 6.77 & 0.012 & 2 & 6.44 & 0.003 \\
C concentrations & 2 & 24.05 & $<0.001$ & 1 & 63.94 & $<0.001$ & 2 & 3.65 & 0.034 \\
N concentrations & 2 & 7.91 & $<0.001$ & 1 & 1.42 & 0.240 & 2 & 11.47 & $<0.001$ \\
C stocks & 2 & 13.42 & $<0.001$ & 1 & 3.52 & 0.001 & 2 & 6.80 & 0.002 \\
N stocks & 2 & 9.52 & $<0.001$ & 1 & 10.73 & 0.001 & 2 & 11.75 & $<0.001$ \\
\hline
\end{tabular}

Table 4. Mean values of ${ }^{14} \mathrm{C}$ content and mean age of fine roots $(<2 \mathrm{~mm})$ among land-use types and study regions (mean $\pm \mathrm{SE}$ ). Two-way ANOVA results are presented with Holm's test $(p<0.05)$. Significant differences between study regions are indicated by lowercase letters and between land-use types by capital letters.

\begin{tabular}{llccc}
\hline Land use & Study region & $n$ & $\begin{array}{c}\text { Fine root } \\
\Delta^{14} \mathrm{C}(\%)\end{array}$ & $\begin{array}{c}\text { Fine root } \\
\text { mean age }\end{array}$ \\
\hline Forest & All plots & $\mathbf{2 7}$ & $\mathbf{9 0} \pm \mathbf{5}^{\mathbf{A}}$ & $\mathbf{1 1 . 3} \pm \mathbf{1 . 8}^{\mathbf{A}}$ \\
& ALB & 9 & $88 \pm 12^{\mathrm{a}}$ & $11.9 \pm 3.0^{\mathrm{a}}$ \\
& HAI & 9 & $94 \pm 6^{\mathrm{a}}$ & $10.6 \pm 0.9^{\mathrm{a}}$ \\
& SCH & 9 & $87 \pm 7^{\mathrm{a}}$ & $10.5 \pm 1.1^{\mathrm{a}}$ \\
Grasslands & All plots & $\mathbf{2 7}$ & $\mathbf{3 6} \pm \mathbf{1}^{\mathbf{B}}$ & $\mathbf{1 . 7} \pm \mathbf{0 . 4}^{\mathbf{B}}$ \\
& ALB & 9 & $40 \pm 2^{\mathrm{b}}$ & $2.6 \pm 0.3^{\mathrm{b}}$ \\
& HAI & 9 & $36 \pm 2^{\mathrm{c}}$ & $1.8 \pm 0.3^{\mathrm{c}}$ \\
& SCH & 9 & $32 \pm 1^{\mathrm{d}}$ & $0.7 \pm 0.1^{\mathrm{d}}$ \\
\hline
\end{tabular}

content (mean: $22 \pm 2$ ), and also decreased significantly for increasing Ellenberg indicator values for soil moisture content and root $\mathrm{N}$ concentrations ( $p<0.05$, Table 5 ). We found no strong relation between $\mathrm{pH}$ and biomass effect on ${ }^{14} \mathrm{C}$ age of fine roots for our grassland study sites. Fertilization, graz- ing and mowing activities as well as the LUI index did not directly influence fine root $\mathrm{C}$ mean age significantly.

\section{Discussion}

\section{1 $\operatorname{Root}^{14} \mathrm{C}$ age difference between grasslands and forests}

Our findings of higher ${ }^{14} \mathrm{C}$ contents in the forest fine roots than in the grassland fine roots by $9 \mathrm{yr}$ support our hypothesis that in forest ecosystems the age of root $\mathrm{C}$ is older than in grasslands (Table 4). We used radiocarbon contents to infer the mean $\mathrm{C}$ age in roots rather than root longevity. Overall the ages of fine root $\mathrm{C}$ were broadly consistent with earlier radiocarbon studies in forest mineral soils and in pastures (Gaudinski et al., 2010, 2001; Sah et al., 2012; Strand et al., 2008; Veldkamp, 1994). Older root C age in the forest sites may be due to higher contents of perennial root tissues or to the ability of tree species to use storage compounds and recycle $\mathrm{C}$ internally on a longer term compared to annual and perennial species in grasslands. Sah et al. (2012) recently concluded from their results that new live tree roots may use old carbon reserves for cellulose formation.

We further found a greater variability in ${ }^{14} \mathrm{C}$ of fine roots in forests than in grasslands. This could be attributed to major 

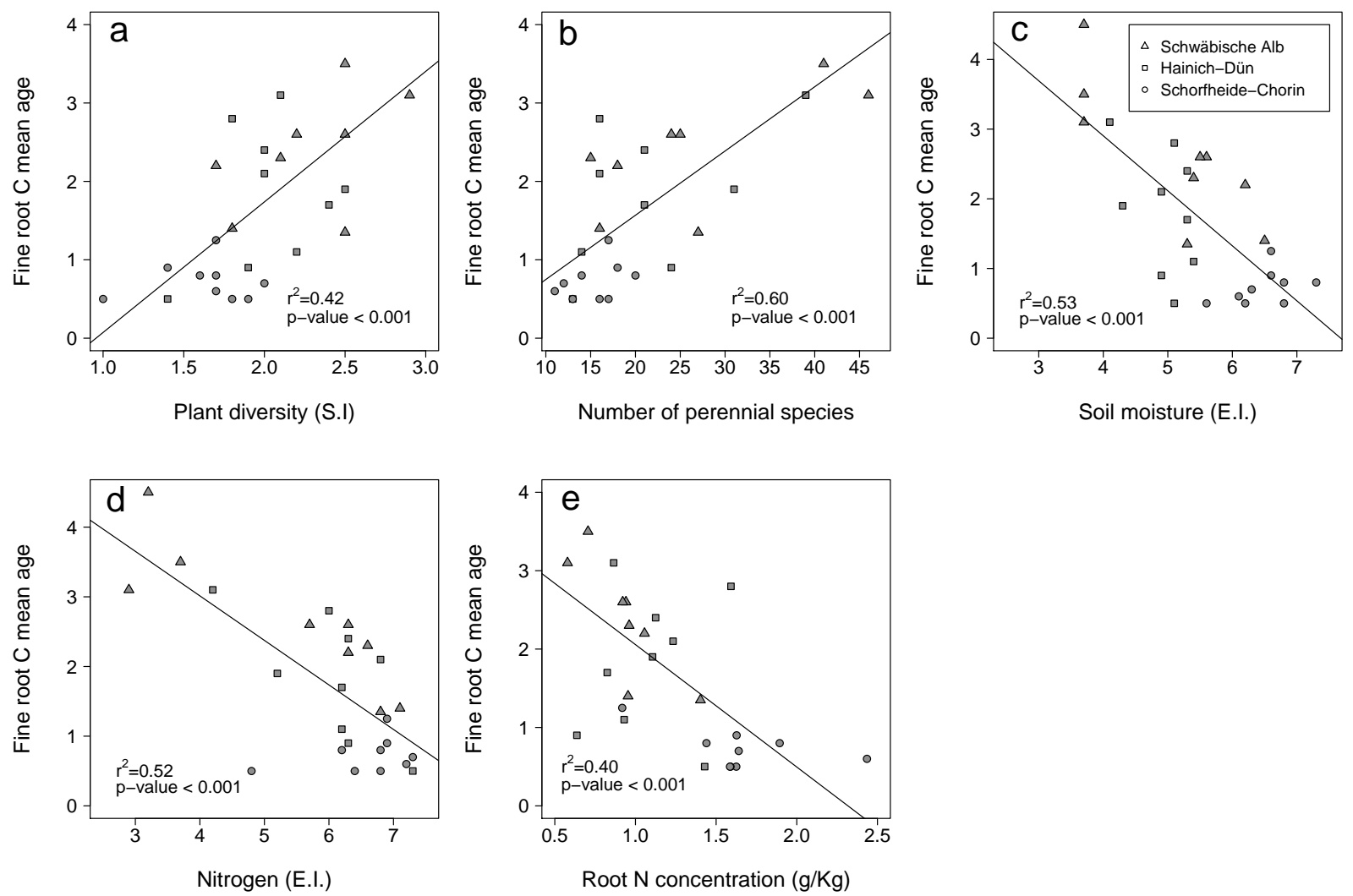

Fig. 3. Relationships between the mean age of fine roots and (a) plant diversity, (b) total number of perennial species, (c) Ellenberg indicator for moisture, (d) Ellenberg indicator for nitrogen, and (e) fine root nitrogen concentration in the grasslands $(n=27)$.

Table 5. Pearson's correlation matrix between variables in grasslands. Numbers in bold indicate a significant correlation $(p<0.05)$. E.I. $=$ Ellenberg indicator values, S.I. $=$ Shannon index $(n=27)$.

\begin{tabular}{|c|c|c|c|c|c|c|c|c|c|}
\hline Trait & $\begin{array}{r}\text { Plant } \\
\text { diversity (S.I) }\end{array}$ & $\begin{array}{r}\text { Perennial } \\
\text { species }\end{array}$ & $\begin{array}{r}\text { Nitrogen } \\
\text { (E.I.) }\end{array}$ & $\mathrm{pH}$ & $\begin{array}{r}\text { Moisture } \\
\text { (E.I.) }\end{array}$ & Fertilization & $\begin{array}{r}\text { Root } \\
\text { biomass }\end{array}$ & $\begin{array}{r}\mathrm{N} \text { conc. } \\
\text { roots }\end{array}$ & $\begin{array}{r}\mathrm{C} \text { conc. } \\
\text { roots }\end{array}$ \\
\hline Root $\mathrm{C}$ mean age & 0.65 & 0.77 & -0.72 & -0.20 & -0.73 & -0.33 & -0.30 & -0.63 & -0.26 \\
\hline Plant diversity (S.I.) & & 0.71 & -0.51 & -0.19 & -0.72 & -0.25 & -0.42 & -0.59 & -0.11 \\
\hline Perennial species & & & -0.88 & -0.02 & -0.79 & -0.41 & -0.16 & -0.64 & -0.06 \\
\hline Nitrogen (E.I.) & & & & -0.06 & 0.69 & 0.31 & -0.01 & 0.54 & -0.06 \\
\hline $\mathrm{pH}$ & & & & & -0.09 & 0.28 & 0.45 & 0.24 & -0.11 \\
\hline Moisture (E.I) & & & & & & 0.29 & 0.28 & 0.60 & 0.38 \\
\hline Fertilization & & & & & & & -0.18 & 0.07 & -0.38 \\
\hline Root biomass & & & & & & & & 0.14 & 0.13 \\
\hline $\mathrm{N}$ conc. roots & & & & & & & & & 0.24 \\
\hline $\mathrm{C}$ conc. roots & & & & & & & & & \\
\hline
\end{tabular}

differences in root-branching and chemistry in fine tree roots compared to fine roots of herbaceous species growing in grasslands (Waisel et al., 2002). Guo et al. (2004) suggested that root age might be related to cellulose content in different root branching orders in trees. Cellulose was observed to increase from the most distal parts of the fine root system (first and second root orders) to the more proximal portions (fifth order roots) (Guo et al., 2004). An inclusion of various root orders with different functions in the selected diameter size class of $<2 \mathrm{~mm}$ is also possible. It might be that forests species produced more variable amounts of short-lived, absorptive roots vs. long-lived, transport/storage roots.

Negative relations between fine root $\mathrm{N}$ concentrations and fine root lifespans have also been previously reported (Tjoelker et al., 2005). Furthermore, patterns of higher N and $P$ concentrations in roots of lower order rather than higher order were observed in four tree species of temperate forests by Goebel et al. (2011). However, we did not see significant 
Table 6. Summary of proportional hazards fit in grasslands $(n=27)$. Risk ratios $<1.0$ represent a positive effect on fine root mean age, and risk ratios $>1.0$ represent a negative effect. Results in bold indicate significant results $(p<0.05)$. (E.I. $=$ Ellenberg indicator values, S.I. $=$ Shannon Index).

\begin{tabular}{lrrr}
\hline Factor & $X^{2}$ & $P>X^{2}$ & Risk ratio \\
\hline Plant diversity (S.I.) & 15.1 & $<\mathbf{0 . 0 0 1}$ & 0.088 \\
Perennial species & 20.8 & $<\mathbf{0 . 0 0 1}$ & 0.88 \\
Nitrogen (E.I.) & 23.1 & $<\mathbf{0 . 0 0 1}$ & 3.99 \\
pH & 0.78 & 0.38 & - \\
Moisture (E.I.) & 19.1 & $<\mathbf{0 . 0 0 1}$ & 3.11 \\
Fertilization & 1.34 & 0.24 & - \\
Root biomass & 2.1 & 0.14 & - \\
N conc. roots & 13.8 & $<\mathbf{0 . 0 0 1}$ & 7.3 \\
C conc. roots & 1.4 & 0.24 & - \\
\hline
\end{tabular}

differences in $\mathrm{N}$ content between roots of forests and grasslands (Table 3), even though they differed markedly in age. Under the assumption that older mean ages of forests are due to longer turnover times rather than internal recycling of $\mathrm{C}$, our observation of less root biomass in forests compared to grasslands suggests overall smaller root litter input to forest than grassland topsoils. We can however only refer to the upper $10 \mathrm{~cm}$ of the mineral soil, and it is possible that in forests litter input to subsoils is larger than in grasslands (Jobbàgy and Jackson, 2000).

\section{2 $\operatorname{Root}^{14} \mathrm{C}$ age in grassland ecosystems}

We confirmed our hypothesis that in grasslands the management effect is reflected in the mean age of fine root $\mathrm{C}$ and is mediated by the total number of perennial species present, by observing that the age of $\mathrm{C}$ in fine roots was significantly greater on sites characterized by a higher plant diversity and total number of perennial species. This relates to the results from a number of ${ }^{14} \mathrm{C}$ pulse labelling studies by Veldkamp (1994) and Milchunas et al. (1985), which demonstrated that $\mathrm{C}$ is recycled in perennial grass roots over a period of years. In contrast, annual plants are constructed almost entirely of contemporary atmospheric-derived $\mathrm{C}$ except what is inherited from their seed.

Although the number of fertilized plots was limited to 12 plots, our results suggest a negative relation between the amount of fertilizer and the total number of perennial species present on the plots (Table 5, $p=0.06$ ). This in turn can reflect in variations of mean age of $\mathrm{C}$ in fine roots. Previous studies have already demonstrated the negative effects of fertilization on species richness (Socher et al., 2012; Stewart and Pullin, 2008; Zechmeister et al., 2003). Recently, a study by Socher et al. (2012) conducted in the same study regions has shown a loss of $19 \%$ of the total number of vascular plant species on a grassland site with an annual fertilization input of $35 \mathrm{~kg}$ of $\mathrm{N}$ per hectare. Given the limited amount of grazed and mowed sites in our dataset, we did not find any significant effect of these management practices on root $\mathrm{C}$ age. We also did not find any significant correlation with soil $\mathrm{pH}$, which was surprising because we expected that soil $\mathrm{pH}$ would vary according to different management schemes (Falkengren-Grerup et al., 2006; Birkhofer et al., 2012).

Addressing our third hypothesis that the ${ }^{14} \mathrm{C}$ content of fine roots differs between study regions due to differences in soil characteristics and climate, we found that in grasslands the variation of ${ }^{14} \mathrm{C}$ age of fine roots among study regions is considerable, with older root C in ALB followed by HAI and $\mathrm{SCH}$. We assume that the annual plant roots with lower than ${ }^{14} \mathrm{C}$ atmospheric values, which we mainly found in the $\mathrm{SCH}$ grasslands, might define the local atmospheric ${ }^{14} \mathrm{C}$. As this effect was not great $(2 \%$ ), we did not correct for the calculated ages. We further believe that regional differences are not due to different levels of contamination because there was no such trend in the adjacent forests. Nevertheless, we cannot exclude the possibility that these roots may have taken up extremely old carbon which was stored in the organic soils, i.e. amino acid $\mathrm{C}$. The ability of herbaceous plant species to take up amino acids was demonstrated by Näsholm et al. (2000).

We did not find the same pattern in the forests, where the larger variability may overprint similar effects and induce management dissimilarities. We relate differences among study regions to variations in climate and soil properties like moisture and nutrient content, which may lead to changes in species diversity and total number of perennial species. Nutrient-poor sites (i.e. ALB) could for example favour perennial species over annual species, reflecting a trade-off between rapid acquisition of resources and conservation of resources (Tjoelker et al., 2005). Older root $\mathrm{C}$ age in nutrientpoor sites may be explained by the necessity of plants to optimize the uptake of nutrients (Sah et al., 2012), for example by reducing carbon and nutrient expenses in fine root production.

The climate gradient across the three study regions could also reflect differences in fine root $\mathrm{C}$ mean age. As the mean temperatures are higher in SCH than in ALB and we collected samples in spring, plants in northern Germany may have grown a larger amount of newly grown roots than plants in southern Germany at the time of sampling. This might have resulted in a relatively larger contribution of young roots in $\mathrm{SCH}$.

Furthermore, variations in perennial root tissue may also occur as a result of plant functional types or phenotypical variation in plants in reaction to different nutrient and energy limitations in the study regions, resulting in root mean age $\mathrm{C}$ changes. The negative correlation between root $\mathrm{C}$ mean age and root $\mathrm{N}$ content (Table 5), which we found in grasslands for example, suggests that larger $\mathrm{N}$ contents of roots with faster turnover could be due to a greater contribution of lower order roots. We also found that root biomass and related $\mathrm{C}$ stocks were greater in more fertile sites characterized by lower ${ }^{14} \mathrm{C}$ content in roots, indicating faster root turnover 
(i.e in $\mathrm{SCH}, \mathrm{HAI}$ ) than in less fertile sites showing higher ${ }^{14} \mathrm{C}$ content in roots (ALB). The largest fine root litter input to the soil therefore probably occurs in the more fertile sites with a large biomass of young roots. Whether this leads to larger soil organic carbon stocks depends on the decomposition rates.

\section{Conclusions}

Our observations of the mean age of fine root $\mathrm{C}$ from forest and grassland sites in Germany indicate that variations in the mean age of fine root $\mathrm{C}$ between tree vs. herbaceous grassland species and annual vs. perennial herbaceous species in grasslands can be associated with differences in root tissue lifetime or in resource acquisition and resource conservation strategies. Differences in plant resource acquisition and maintenance strategies are in turn reflected by the ability of recycling $\mathrm{C}$ internally. The mean age of root $\mathrm{C}$ in grasslands is affected by changes in plant species diversity and in the number of perennial species due to changes in soil moisture and available nutrients in the soil, which in turn may be influenced by different management practices. Therefore, plant diversity indices or other easy to measure parameters like the Ellenberg indicator values for "nitrogen" or "moisture" are potentially applicable by grassland ecologists and modellers to make some first speculations about the turnover time of root $\mathrm{C}$ in their field sites. They are therefore of particular importance for further understanding and descriptions of management influences on belowground processes to be included in climate and landscape models.

We suggest additional efforts to improve our knowledge of how the internal redistribution dynamics of $\mathrm{C}$ occurs in perennial plant species and in roots with different roles (absorbtion, transport and storage) belonging to different species and plant functional types. This would enable separation of the age of $\mathrm{C}$ into a recycling component and a newly grown component and allow estimation of the root lifetimes from ${ }^{14} \mathrm{C}$ data.

Acknowledgements. We thank Ines Hilke and Birgit Fröhlich for the CN analysis, Axel Steinhof and Heike Machts for the radiocarbon analysis and Theresa Klötzing for technical support. We thank the managers of the three exploratories, Swen Renner, Sonja Gockel, Kerstin Wiesner, and Martin Gorke, for their work in maintaining the plot and project infrastructure; Simone Pfeiffer and Christiane Fischer for giving support through the central office, Michael Owonibi for managing the central data base, and Markus Fischer, Eduard Linsenmair, Dominik Hessenmöller, Jens Nieschulze, Daniel Prati, François Buscot, Ernst-Detlef Schulze, Wolfgang W. Weisser and the late Elisabeth Kalko for their role in setting up the Biodiversity Exploratories project. The work has been funded by the DFG Priority Program 1374 "Infrastructure-Biodiversity-Exploratories" (SCHR 1181/2-1) and the Max Planck Society. Field work permits were issued by the responsible state environmental offices of Baden-Württemberg,
Thüringen, and Brandenburg (according to $\S 72 \mathrm{BbgNatSchG)}$ ). Emily Solly conducted this work as part of the International Max Planck Research school for Global Biogeochemical Cycles.

The service charges for this open access publication have been covered by the Max Planck Society.

Edited by: P. Stoy

\section{References}

Birkhofer, K., Schöning, I., Alt, F., Herold, N., Klarner, B., Maraun, M., Marhan, S., Oelmann, Y., Wubet, T., Yurkov, A., Begerow, D., Berner, D., Buscot, F., Daniel, R., Diekötter, T., Ehnes, R. B., Erdmann, G., Fischer, C., Foesel, B., Groh, J., Gutknecht, J., Kandeler, E., Lang, C., Lohaus, G., Meyer, A., Nacke, H., Näther, A., Overmann, J., Polle, A., Pollierer, M. M., Scheu, S., Schloter, M., Schulze, E. D., Schulze, W., Weinert, J., Weisser, W. W., Wolters, V., and Schrumpf, M.: General Relationships between Abiotic Soil Properties and Soil Biota across Spatial Scales and Different Land-Use Types, PLoS One, 7, e43292, doi:10.1371/journal.pone.0043292, 2012.

Blüthgen, N., Dormann, C. F., Prati, D., Klaus, V. H., Kleinebecker, T., Hölzel, N., Alt, F., Boch, S., Gockel, S., Hemp, A., Müller, J., Nieschulze, J., Renner, S. C., Schöning, I., Schumacher, U., Socher, S. A., Wells, K., Birkhofer, K., Buscot, F., Oelmann, Y., Rothenwöhrer, C., Scherber, C., Tscharntke, T., Weiner, C. N., Fischer, M., Kalko, E. K. V., Linsenmair, K. E., Schulze, E. D., and Weisser, W. W.: A quantitative index of land-use intensity in grasslands: Integrating mowing, grazing and fertilization, Basic Appl. Ecol., 13, 207-220, doi:10.1016/j.baae.2012.04.001, 2012.

Brunner, I. and Godbold, D. L.: Tree roots in a changing world, J. Forest Res., 12, 78-82, doi:10.1007/s10310-006-0261-4, 2007.

Chapin III, F. S., , Matson, P. A., and Mooney, H. A.: Principles of terrestrial ecosystem ecology, Springer-Verlag New York Inc., 175 Fifth Avenue, New York, NY, 10010-7858, USA D-6900, Heidelberg, Germany, 1-436, 2002.

Cox, D. R.: Regression models and life-tables, J. R. Stat. Soc. Ser. B-Stat. Methodol., 34, 187-220, 1972.

Ellenberg, H., Weber, H. E., Dull, R., Wirt, V., and Werner, W.: Zeigerwerte von Pflanzen in Mitteleuropa, Scr. Geobot., 18, 1262, 2001.

Falkengren-Grerup, U., ten Brink, D. J., and Brunet, J.: Land use effects on soil N, P, C and pH persist over 40-80 years of forest growth on agricultural soils, Forest Ecol. Manag., 225, 74-81, doi:10.1016/j.foreco.2005.12.027, 2006.

Fischer, M., Bossdorf, O., Gockel, S., Hänsel, F., Hemp, A., Hessenmöller, D., Korte, G., Nieschulze, J., Pfeiffer, S., Prati, D., Renner, S., Schöning, I., Schumacher, U., Wells, K., Buscot, F., Kalko, E. K. V., Linsenmair, K. E., Schulze, E. D., and Weisser, W. W.: Implementing large-scale and long-term functional biodiversity research: The Biodiversity Exploratories, Basic Appl. Ecol., 11, 473-485, doi:10.1016/j.baae.2010.07.009, 2010.

Fröberg, M.: Residence time of fine-root carbon using radiocarbon measurements of samples collected from a soil archive, J. Plant Nutr. Soil Sc., 175, 46-48, doi:10.1002/jpln.201100072, 2012.

Gaudinski, J. B., Trumbore, S. E., Davidson, E. A., Cook, A. C., Markewitz, D., and Richter, D. D.: The age of fine-root carbon in 
three forests of the eastern United States measured by radiocarbon, Oecologia, 129, 420-429, 2001.

Gaudinski, J. B., Torn, M. S., Riley, W. J., Dawson, T. E., Joslin, J. D., and Majdi, H.: Measuring and modeling the spectrum of fine-root turnover times in three forests using isotopes, minirhizotrons, and the Radix model, Glob. Biogeochem. Cy., 24, Gb3029, doi:10.1029/2009GB003649, 2010.

Goebel, M., Hobbie, S. E., Bulaj, B., Zadworny, M., Archibald, D. D., Oleksyn, J., Reich, P. B., and Eissenstat, D. M.: Decomposition of the finest root branching orders: linking belowground dynamics to fine-root function and structure, Ecol. Monogr., 81, 89-102, doi:10.1890/09-2390.1, 2011.

Guo, D. L., Mitchell, R. J., Withington, J. M., Fan, P. P., and Hendricks, J. J.: Endogenous and exogenous controls of root life span, mortality and nitrogen flux in a longleaf pine forest: root branch order predominates, J. Ecol., 96, 737-745, doi:10.1111/j.1365-2745.2008.01385.x, 2008.

Hättenschwiler, S., Tiunov, A. V., and Scheu, S.: Biodiversity and litter decomposition interrestrial ecosystems, in: Annual Review of Ecology Evolution and Systematics, Ann. Rev. Ecol. Evol. S., Palo Alto, 36, 191-218, 2005.

Hobbie, S. E.: Effects of plant-species on nutrient cycling, Trends Ecol. Evol., 7, 336-339, doi:10.1016/0169-5347(92)90126-v, 1992.

Jackson, R. B., Mooney, H. A., and Schulze, E. D.: A global budget for fine root biomass, surface area, and nutrient contents, P. Natl. Acad. Sci. USA, 94, 7362-7366, doi:10.1073/pnas.94.14.7362, 1997.

Jobbàgy, E. G. and Jackson, R. B.: The vertical distribution of soil organic carbon and its relation to climate and vegetation, Ecol. Appl., 10, 423-436, doi:10.2307/2641104, 2000.

Laliberté, E., Wells, J. A., DeClerck, F., Metcalfe, D. J., Catterall, C. P., Queiroz, C., Aubin, I., Bonser, S. P., Ding, Y., Fraterrigo, J. M., McNamara, S., Morgan, J. W., Merlos, D. S., Vesk, P. A., and Mayfield, M. M.: Land-use intensification reduces functional redundancy and response diversity in plant communities, Ecol. Lett., 13, 76-86, doi:10.1111/j.1461-0248.2009.01403.x, 2010.

Levin, I., Naegler, T., Kromer, B., Diehl, M., Francey, R. J., GomezPelaez, A. J., Steele, L. P., Wagenbach, D., Weller, R., and Worthy, D. E.: Observations and modelling of the global distribution and long-term trend of atmospheric $\left(\mathrm{CO}_{2}\right)-\mathrm{C}-14$, Tellus $\mathrm{B}, 62$, 207-207, doi:10.1111/j.1600-0889.2010.00456.x, 2010.

Lukac, M.: Fine Root Turnover, Measuring Roots: An Updated Approach, edited by: Mancuso, S., Springer, 233 Spring Street, New York, Ny 10013, USA, 363-373, 2012.

Luyssaert, S., Hessenmöller, D., von Lüpke, N., Kaiser, S., and Schulze, E. D.: Quantifying land use and disturbance intensity in forestry, based on the self-thinning relationship, Ecol. Appl., 21, 3272-3284, 2011.

Majdi, H., Pregitzer, K., Morén, A. S., Nylund, J. E., and Ågren, G. I.: Measuring fine root turnover in forest ecosystems, Plant Soil, 276, 1-8, doi:10.1007/s11104-005-3104-8, 2005.

Matamala, R., Gonzàlez-Meler, M. A., Jastrow, J. D., Norby, R. J., and Schlesinger, W. H.: Impacts of fine root turnover on forest NPP and soil C sequestration potential, Science, 302, 13851387, doi:10.1126/science.1089543, 2003.

Milchunas, D. G., Lauenroth, W. K., Singh, J. S., Cole, C. V., and Hunt, H. W.: Root turnover and production by C-14 dilution Implications of carbon partitioning in plants, Plant Soil, 88, 353-
365, doi:10.1007/bf02197492, 1985.

Naegler, T. and Levin, I.: Closing the global radiocarbon budget 1945-2005, J. Geophys. Res.-Atmos., 111, D12311, doi:10.1029/2005jd006758, 2006.

Näsholm, T., Huss-Danell, K., and Högberg, P.: Uptake of organic nitrogen in the field by four agriculturally important plant species, Ecology, 81, 1155-1161, doi:10.1890/00129658(2000)081[1155:uoonit]2.0.co;2, 2000.

Ostle, N. J., Smith, P., Fisher, R., Woodward, F. I., Fisher, J. B., Smith, J. U., Galbraith, D., Levy, P., Meir, P., McNamara, N. P., and Bardgett, R. D.: Integrating plant-soil interactions into global carbon cycle models, J. Ecol., 97, 851-863, doi:10.1111/j.13652745.2009.01547.x, 2009.

R Development Core Team R: A language and environment for statistical computing, R 551 Foundation for Statistical Computing, Vienna. Computing, Vienna, Austria, ISBN 3-552 900051-07-0, http://www.R-project.org/, (last acces: 6 June 2013), 2012.

Randerson, J. T., Enting, I. G., Schuur, E. A. G., Caldeira, K., and Fung, I. Y.: Seasonal and latitudinal variability of troposphere Delta $\left(\mathrm{CO}_{2}\right)-\mathrm{C}-14$ : Post bomb contributions from fossil fuels, oceans, the stratosphere, and the terrestrial biosphere, Glob. Biogeochem. Cy., 16, 1112, doi:10.1029/2002gb001876, 2002.

Riley, W. J., Gaudinski, J. B., Torn, M. S., Joslin, J. D., and Hanson, P. J.: Fine-root mortality rates in a temperate forest: estimates using radiocarbon data and numerical modeling, New Phytol., 184, 387-398, doi:10.1111/j.1469-8137.2009.02980.x, 2009.

Sah, S. P., Bryant, C. L., Leppälammi-Kujansuu, J., Löhmus, K., Ostonen, I., and Helmisaari, H. S.: Variation of carbon age of fine roots in boreal forests determined from ${ }^{14} \mathrm{C}$ measurements, Plant Soil, 363, 77-86, doi:10.1007/s11104-012-1294-4, 2012.

Schaffers, A. P. and Sýkora, K. V.: Reliability of Ellenberg indicator values for moisture, nitrogen and soil reaction: a comparison with field measurements, J. Veg. Sci., 11, 225-244, doi:10.2307/3236802, 2000.

Schmidt, M. W. I., Torn, M. S., Abiven, S., Dittmar, T., Guggenberger, G., Janssens, I. A., Kleber, M., Koegel-Knabner, I., Lehmann, J., Manning, D. A. C., Nannipieri, P., Rasse, D. P., Weiner, S., and Trumbore, S. E.: Persistence of soil organic matter as an ecosystem property, Nature, 478, 49-56, doi:10.1038/nature10386, 2011.

Shannon, C. E.: A mathematical theory of communication, Bell Syst. Tech. J., 27, 379-423, 1948.

Socher, S. A., Prati, D., Boch, S., Müller, J., Klaus, V. H., Hölzel, N., and Fischer, M.: Direct and productivity-mediated indirect effects of fertilization, mowing and grazing on grassland species richness, J. Ecol., 100, 1391-1399, doi:10.1111/j.13652745.2012.02020.x, 2012.

Steinhof, A., Adamiec, G., Gleixner, G., van Klinken, G. J., and Wagner, T.: The new C-14 analysis laboratory in Jena, Germany, Radiocarbon, 46, 51-58, 2004.

Stewart, G. B. and Pullin, A. S.: The relative importance of grazing stock type and grazing intensity for conservation of mesotrophic 'old meadow' pasture, J. Nat. Conserv., 16, 175185, doi:10.1016/j.jnc.2008.09.005, 2008.

Strand, A. E., Pritchard, S. G., McCormack, M. L., Davis, M. A., and Oren, R.: Irreconcilable differences: Fine-root life spans and soil carbon persistence, Science, 319, 456-458, doi:10.1126/science.1151382, 2008. 
Stuiver, M. and Polach, H. A.: Discussion: Reporting of ${ }^{14} \mathrm{C}$ Data, Radiocarbon, 19, 355-363, 1977.

Tierney, G. L. and Fahey, T. J.: Fine root turnover in a northern hardwood forest: a direct comparison of the radiocarbon and minirhizotron methods, Can. J. Forest Res., 32, 1692-1697, doi:10.1139/x02-123, 2002.

Tilman, D., Wedin, D., and Knops, J.: Productivity and sustainability influenced by biodiversity in grassland ecosystems, Nature, 379, 718-720, doi:10.1038/379718a0, 1996.

Tjoelker, M. G., Craine, J. M., Wedin, D., Reich, P. B., and Tilman, D.: Linking leaf and root trait syndromes among 39 grassland and savannah species, New Phytol., 167, 493-508, doi:10.1111/j.1469-8137.2005.01428.x, 2005.

Torn, M., Swanston, C., Castanha, C., and Trumbore, S.: Storage and turnover of organic matter in soil, Biophysico-chemical processes involving natural nonliving organic matter in environmental systems, Wiley, Hoboken, 219-272, 2009.
Trumbore, S.: Radiocarbon and Soil Carbon Dynamics, Annu. Rev. Earth Planet. Sci., 37, 47-66, doi:10.1146/annurev.earth.36.031207.124300, 2009.

Trumbore, S. E. and Gaudinski, J. B.: The secret lives of roots, Science, 302, 1344-1345, doi:10.1126/science.1091841, 2003.

Veldkamp, E.: Organic-carbon turnover in 3 tropical soils under pasture after deforestation, Soil Sci. Soc. Am. J., 58, 175-180, 1994.

Waisel, Y., Eshel, A., and Kafkafi, U.: Plant-roots - the hidden half. 3rd Edn., 6, Marcel Decker, New York, 775-776, 2002.

Zechmeister, H. G., Schmitzberger, I., Steurer, B., Peterseil, J., and Wrbka, T.: The influence of land-use practices and economics on plant species richness in meadows, Biol. Conserv., 114, 165-177, doi:10.1016/s0006-3207(03)00020-x, 2003. 